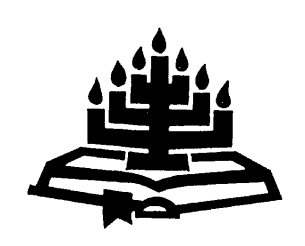

\title{
'n Beoordeling van die vernaamste kerklike en teologiese tradisies se bydrae tot die etiek van sosio-ekonomiese regte
}

\author{
H.M. Zwemstra \\ Skool vir Kerkwetenskappe \\ Potchefstroomkampus \\ Noordwes-Universiteit \\ POTCHEFSTROOM \\ E-pos: heinrich@zwemstra.org
}

\begin{abstract}
An adjudication of the most prominent ecclesiastical and theological traditions to the ethics of socio-economical rights In this article the contribution of the Roman Catholic Church and that of the main protestant churches to the ethics of socioeconomical rights is investigated and adjudicated. The Roman Catholic Church stresses the importance of socio-economic rights, but socio-economic rights are founded in natural law and not in Biblical principles. In the Lutheran tradition socioeconomic rights are ascribed to the domain of the world, and no proper Biblical foundation is given. The World Alliance of Reformed Churches gives a Biblical foundation to socio-economic rigths, but unfortunately it is influenced by political theology. The Testimony on Human Rights of the Reformed Ecumenical Synod is a comprehensive study on human rights in the reformed tradition, and proper Biblical foundation is given to socio-economic rights.
\end{abstract}

\section{Opsomming}

'n Beoordeling van die vernaamste kerklike en teologiese tradisies se bydrae tot die etiek van sosio-ekonomiese regte

Die bydraes van die Rooms-Katolieke Kerk en die vernaamste protestantse kerke tot die etiek van sosio-ekonomiese regte word in hierdie artikel ondersoek en beoordeel. Die RoomsKatolieke Kerk beklemtoon die belangrikheid van sosio-ekonomiese regte, maar sosio-ekonomiese regte word in die natuurreg gefundeer en nie in Bybelse beginsels nie. In the Lutherse tradisie word sosio-ekonomiese regte aan die domein van die 
wêreld toegeskryf, en geen goeie Bybelse fundering word gegee nie. Die World Alliance of Reformed Churches gee 'n Bybelse fundering aan sosio-ekonomiese regte, maar ongelukkig is dit beïnvloed deur die politieke teologie. Die Testimony on Human Rights van die Gereformeerde Ekumeniese Raad is 'n omvattende studie oor menseregte in die gereformeerde tradisie, en goeie Bybelse fundering word aan sosio-ekonomiese regte gegee.

\section{Inleiding}

Die kerke in Europa het 'n oorwegend negatiewe houding ingeneem teenoor die eerste verklarings ten opsigte van menseregte. Tog was daar nog altyd individuele Christene wat die saak van menseregte goedgesind was en dit bevorder het (De Villiers, 1984:20). Die negatiewe ingesteldheid van die kerke kan toegeskryf word aan die feit dat menseregte die bevoorregte posisie van die Rooms-Katolieke Kerk tydens die Franse Revolusie uitgedaag het (De Villiers, 1984: 21). Die Franse Revolusie het kerke verder negatief teenoor menseregte gestem toe terreurdade teen die kerk gepleeg is onder die vaandel van vryheid, gelykheid en broederskap (De Villiers, 1984: 21). Die Rooms-Katolieke Kerk, maar ook ander staatskerke in Europa, het menseregte gevolglik beskou as 'n totale revolusionêre aanslag teen die bestaande politieke en kerklike orde (De Villiers, 1984:21).

'n Verdere rede vir die kerk se verset teen die leerstuk van menseregte, is die humanistiese en sekulêre denke van die Verligting. Met die redelikheid van die mens as uitgangspunt, het die Verligting verskeie menseregte geformuleer wat in die inherente natuur van die mens sou setel (Vorster, 2002:176). Die humanisme van die Verligting se antropologiese werklikheidsbeskouing het te staan gekom teenoor die teosentriese werklikheidsbeskouing van die kerk. Hierdie optimistiese mensbeskouing was vir die kerke onaanvaarbaar en onversoenbaar met die radikale verdorwenheid van die mens. Die kerk het menseregte daarom as rasionalisties, optimisties, individualisties en sekularisties veroordeel (De Villiers, 1984:21, 22).

Kerke het aanvanklik ook 'n negatiewe benadering gehad teenoor sosio-ekonomiese regte as tweedegenerasie menseregte. Sosioekonomiese regte is geïdentifiseer met sosialisme wat privaatbesit in gemeenskaplike besit wil omskep (vgl. Leo XIII, 1946:263). By baie kerke het die tradisionele sosialistiese lande ook 'n anti-reli- 
gieuse konnotasie gehad wat verder bygedra het tot die negatiewe siening van sosio-ekonomiese regte.

Tog het kerklike en teologiese tradisies se houding teenoor menseregte gaandeweg verander, sodat hulle 'n waardevolle bydrae tot die etiek van menseregte, spesifiek sosio-ekonomiese regte, gelewer het. Daarom sal die bydraes van die Rooms-Katolieke Kerk en die protestantse kerke vervolgens ondersoek word. Binne die protestantse kerke word aandag gegee aan die Wêreldraad van Kerke, die Lutherse tradisie en die gereformeerde tradisie.

\section{Die Rooms-Katolieke Kerk}

Die eerste fase van die Roomse Kerk se bydrae tot die etiek van sosio-ekonomiese regte het aan die einde van die negentiende eeu by Pous Leo XIII (1878-1903) begin. Hy lewer kritiek op die klassieke menseregte. Vir hom is die leerstuk van die klassieke menseregte 'n liberalistiese vryheidsbeskouing wat ' $n$ bedreiging vir die staat en die kerk inhou (De Villiers, 1984:31). In sy maatskaplike ensikliek, Rerum novarum, maak hy voorsiening vir verskeie ekonomiese, sosiale en religieuse regte. Die wanpraktyke van die Industriële Revolusie veroorsaak dat hy hom veral toespits op die regte van arbeiders (vgl. Broeckx, 1946:17; Leo XIII, 1946:261, 262).

Leo XIII verset hom teen die sosialisme, wat alle privaatbesit in gemeenskaplike besit wil omskep. Volgens hom benadeel dit die arbeiderstand, is dit onregverdig teenoor regmatige besitters, misvorm dit die taak van die staat en bring dit volslae verwarring in die maatskappy tot stand (Leo XIII, 1946:263). Teenoor die sosialisme, lê Leo XIII groot klem op die ekonomiese reg van individue. In aansluiting by die natuurlike teologie van Thomas van Aquino het Leo XIII hom telkens beroep op die natuurreg (vgl. Leo XIII, 1946:263, 264; Vorster, 2002:178). Volgens hom het die mens die natuurlike reg op alle basiese middele wat nodig is vir 'n menslike bestaan (vgl. Vorster, 2002:178). Dit sluit in die reg om te staak, om te rus, regverdige werksure en werksomstandighede, kontrakte tussen werknemers en werkgewers en billike belasting (Leo XIII, 1946:271, 281-286). Verder mag kinders ook nie arbeid verrig voordat hulle liggaamlik daartoe in staat is nie, en die staat moet sorg vir die welsyn van die werkersklas, die regte van individue en die regte van arm en weerlose mense (Leo XIII, 1946:280-283).

Tussen die twee wêreldoorloë het Pous Pius XI (1922-1939) voortgebou op Leo XIII se siening van sosio-ekonomiese regte. In sy ensikliek, Quadragesimo anno, brei hy uit op Rerum novarum en 
pleit hy ook vir die waardige behandeling van alle mense, ook op ekonomiese en sosiale gebied (Pius XI, 1946:298). Ná die Tweede Wêreldoorlog fundeer Pous Johannes XXIII menseregte in eienskappe wat die mens van nature besit, waarvan redelikheid en vryheid die vernaamste is. Omdat God die mens na sy beeld geskape het, besit die mens hierdie eienskappe (John XXIII, 1963:392, 393). Hierdie gedagtegang kry ons ook by die natuurregleer van Thomas van Aquino. Die lex aeterna (ewigheidsreg) is God se wil vir die heelal en hieruit word die lex naturae (natuurreg) afgelei, wat onskeibaar deel is van die mens se rede. Omdat die mens 'n natuurlike rede het, het hy dus natuurlike menseregte (Van der Vyver, 1975: 10, 11).

Behalwe vir politieke en burgerlike regte, erken Johannes XXIII ook sosio-ekonomiese regte in Pacem in terris. Hierdie regte sluit die reg op werk in en die reg op 'n voldoende lewenstandaard (John XXIII, 1963:180). Hierdie regte plaas twee korrelerende pligte op die individu. In die eerste plek het hy 'n verpligting teenoor homself. Die reg op 'n voldoende lewenstandaard vereis byvoorbeeld dat hy dienooreenkomstig op 'n waardige wyse moet leef. In die tweede plek plaas dit die verpligting op die individu om soortgelyke regte van ander mense te eerbiedig en te beskerm (John XXIII, 1963:397, 400).

Die Rooms-Katolieke Kerk het hulle siening oor sosio-ekonomiese regte verder uitgebrei in die pastorale konstitusie oor die kerk (Gaudium et spes) en in die dokument "Geregtigheid in die wêreld" wat die standpunt van die biskopsinode van 1971 weergee. Volgens hierdie dokumente het die mens regte, omdat hy van nature waardigheid besit. Op die biskopsinode van 1974 is 'n samevattende indeling gemaak van al die menseregte wat nodig geag is om in 'n omvattende sin waardigheid aan die mens te gee (vgl. De Villiers, 1984:31, 32).

\section{Die protestantse kerke}

Die protestantse kerke se bydrae tot die etiek van menseregte het hoofsaaklik in die twintigste eeu begin. In die veertiger- en vyftigerjare is hierdie kerke se betrokkenheid by menseregte beheers deur hulle verset teen die Nazi-regering in Duitsland en die kommunistiese regering in Rusland. Die gevolg was dat die kerk se stryd om die handhawing van menseregte hoofsaaklik gegaan het oor die handhawing van die klassieke vryheidsregte, en in die besonder oor godsdiensvryheid as 'n mensereg (De Villiers, 1984:33). 
In die sestigerjare het protestantse kerke die belangrikheid van sosio-ekonomiese regte toenemend begin insien. Dit was veral die stryd van kerke in ontwikkelende lande teen kolonialistiese en neokolonialistiese uitbuiting, en die teologie van bevryding wat hierdie regte onder die aandag van protestantse kerke gebring het (vgl. De Villiers, 1984:33, 34). Veral binne die Wêreldraad van Kerke het sosio-ekonomiese regte 'n prominente plek begin inneem.

Die Lutherse Wêreldfederasie (LWF) het in 1976 in Genève 'n konferensie oor menseregte gehou (Vorster, 2002:187). Die resultate van die konferensie is in Theologische Perspektiven der Menschenrechte gepubliseer. Hierdie dokument is 'n samevatting van die siening van die Lutherse tradisie ten opsigte van menseregte.

Binne die gereformeerde tradisie is daar twee dokumente wat vir menseregte van belang is, naamlik The theological basis of human rights van die World Alliance of Reformed Churches (WARC), en die Testimony on human rights van die Gereformeerde Ekumeniese Sinode. Omdat die Gereformeerde Ekumeniese Sinode se naam verander het na die Gereformeerde Ekumeniese Raad (GER), sal daar op laasgenoemde manier na hulle verwys word.

\subsection{Die Wêreldraad van Kerke}

Die prominente plek wat sosio-ekonomiese regte op ekumeniese vergaderings begin inneem het, kan duidelik gesien word in veranderings wat binne die Wêreldraad van Kerke (WRK) begin intree het. Aanvanklik het die WRK direk na die Tweede Wêreldoorlog klem gelê op burgerlike en politieke regte, en die reg op godsdiensvryheid (vgl. Vorster, 2002:205, 206). Kerke uit ontwikkelende lande het egter gedurende die sestigerjare al hoe meer verteenwoordiging op die WRK begin kry. Hierdie feit, en die ontwikkeling van die bevrydingsteologie, het veroorsaak dat daar binne hierdie ekumeniese liggaam 'n paradigmaskuif ontstaan het (vgl. De Villiers, 1984:34). Volgens Vorster (2002:207) kan die Church and Societykonferensie, wat in 1966 in Genève gehou is, as 'n draaipunt in die geskiedenis van die Wêreldraad van Kerke beskou word. Tydens hierdie konferensie is ongeregtigheid vanuit die oogpunt van die armes belig, en is daar klem gelê op die gaping tussen ryk en arm lande wat oorbrug moet word (vgl. WCC, 1975b:134).

Dat die WRK deur die bevrydingsteologie beïnvloed is, is duidelik uit die volgende stelling wat tydens die WRK se vergadering in Uppsala in 1968 gemaak is: 
The Word of God testifies that Christ takes the side of the poor and the oppressed. We Christians, who have not always taken sides as He did, now see a worldwide struggle for economic justice. We should work to vindicate the right of the poor and oppressed and to establish economic justice among the nations and within each state. (WCC, 1968:61.)

Tydens Uppsala en ander konferensies en vergaderings wat sou volg, het die WRK die belangrikheid van sosio-ekonomiese regte oor en oor beklemtoon.

In 1974 het die WRK 'n internasionale konferensie oor menseregte in St. Pölten gehou. Samesprekings is gevoer oor maniere waarop menseregte in die wêreld geïmplementeer kan word. Die Christelike liefde is gesien as die diepste motief vir die realisering van menseregte. Tydens hierdie samespreking is 'n indeling van menseregte gedoen en is daar gepoog om die sogenaamde teenstelling tussen sosio-ekonomiese regte en politieke en burgerlike regte te oorbrug. Klem is gelê op die ondeelbaarheid van die verskillende menseregte soos dit in die Universele verklaring van Menseregte, die Internasionale Konvensie oor Ekonomiese, Sosiale en Kulturele Regte, en die Internasionale Konvensie oor Burgerlike en Politieke Regte gevind word (WCC, 1974:35; vgl. De Villiers, 1984:34, 35). Klem is ook gelê op die regte van mense in derdewêreldlande wat die slagoffers van kolonialisme en imperialisme was (WCC, 1974:36).

Net soos in Uppsala in 1968, is die byeenkoms van die WRK in 1975 in Nairobi sterk deur die bevrydingsteologie beïnvloed. Temas van geregtigheid, solidariteit en bevryding kenmerk Nairobi se verslag oor menseregte (vgl. Vorster, 2002:209). Christus word voorgehou as 'n leier wat Hom beywer het vir die regte van armes en onderdruktes (WCC, 1975a:101). In die Nairobi-verslag word tien menseregtekategorieë onderskei, naamlik die reg op basiese lewensbehoeftes, die reg op selfbeskikking, die reg op kulturele identiteit, die regte van minderhede, die reg om deel te hê aan die besluitnemingsproses binne 'n gemeenskap, die reg op verskil van mening, die reg op persoonlike waardigheid, die reg op godsdiensvryheid, en die vryheid van geslagsdiskriminasie en rassisme (WCC, 1975a:103-106).

Ander vergaderings wat deur die WRK gehou is waar die belangrikheid van sosio-ekonomiese regte beklemtoon is, is dié in Vancouver (1983) en Canberra (1991). In die verklaring van Diakonia 2000 call to be neigbours wat in 1986 uitgereik is, word gepleit vir konfrontasie met onregverdige sosiale strukture (WCC, 1987:123). 
Interkerklike hulp het ook te doen met die stryd teen ongeregtigheid, armoede en onderdrukking (WCC, 1991:133).

Nadat die WRK in 1998 'n internasionale konferensie oor menseregte in Morges, Switserland, gehou het, is in 1999 in Harare 'n nuwe verklaring oor menseregte deur die WRK uitgereik. In hierdie verklaring word aan verskeie menseregte aandag gegee, ook sosioekonomiese regte. Alle regte is belangrik en is interafhanklik van mekaar (WCC, 1999:194-198). Die Harare-verklaring beklemtoon die noodsaaklikheid van menseregte vir menslike eenheid (WCC, 1999:199). Uit die Harare-verklaring is dit ook duidelik dat die WRK daartoe geneig is om insigte uit ander godsdienste en kulture oor menseregte onkrities oor te neem (WCC, 1999:204). Deur God se algemene genade kan ander godsdienste en kulture ' $n$ waardevolle bydrae lewer tot menseregte (vgl. Calvyn, 1984:96; Inst. 2.8.1). Die Christelike godsdiens moet egter altyd sulke insigte prinsipieel beoordeel.

Samevattend kan dus gesê word dat die WRK tydens die sestigerjare van die vorige eeu begin het om die belangrikheid van sosio-ekonomiese regte sterk te beklemtoon. Die beskerming en realisering van sosio-ekonomiese regte is begrond in die bevrydingsteologie, wat die sosiale en ekonomiese bevryding van die mens voorop stel. Tussen 1966-1975 is geweld voorgehou as 'n toelaatbare middel om onderdrukkende strukture omver te werp. Die Harare-verklaring het egter ' $n$ meer gematigde benadering begin inneem.

\subsection{Die Lutherse tradisie}

Die Lutherse tradisie se dokument oor menseregte, Theologische Perspektiven der Menschenrechte, beklemtoon die universele karakter van menseregte. Menseregte het egter ook 'n plaaslike karakter, want die realisering van menseregte is afhanklik van heersende sosio-ekonomiese, kulturele en historiese toestande. Sommige menseregte, soos byvoorbeeld die regte van vroue en kinders, moet voorrang geniet in kontekste waar dit geskend is. Basiese universele menseregte moet egter altyd erken word (LWF, 1978:45).

Universele menseregte word omskryf as

$\ldots$ the right to life and the inviolability of the person, in particularly liberty of thought, conscience and religion, and also the right to equality of men and women, children and old peoples, the rights to participate in society and the right to 
share in political and economic decisions, as also the right to cultural identity and national self-determination (LWF, 1978:45).

Die Lutheran World Federation (LWF) beklemtoon individuele regte (politieke en burgerlike regte) en kollektiewe regte (sosio-ekonomiese regte). Fundamentele individuele regte (die reg op lewe, op persoonlike waardigheid, vryheid van denke, gewete, en godsdiens) moet deur elke politieke sisteem gerespekteer word (LWF, 1978:46).

Sosiale regte moet nie net deur elke gemeenskap gewaarborg word nie, maar elke gemeenskap moet ook klem lê op die verantwoordelikheid wat sy burgers teenoor hierdie regte het. Elke gemeenskap moet nie net burgers se menseregte beskerm nie, maar hy moet sy burgers die geleentheid gee om te deel in politieke, sosiale en ekonomiese verantwoordelikheid (LWF, 1978:46).

Volgens die LWF (1978:46) kan kollektiewe regte beperkend inwerk op individuele regte.

The rights to personal freedom and personal economic initiative are at the same time limited and supplemented by the rights of the community: Limited, in so far as the individual rights of individual persons and of whole groups are bounded by the rights of others and of the community, supplemented, in so far as the modern state also takes responsibility for securing the material foundations of life for its citizens.

Vorster (2002:187) merk tereg op dat die Lutherse standpunt oor menseregte baie sterk deur 'n tweeterreineleer gekenmerk word. Op grond van Luther se onderskeiding tussen wet en evangelie word die hele lewe in twee ryke ingedeel. Die een is die ryk van God, en die ander is die ryk van die wêreld. Die ryk van God is die sfeer van die kerk. Dit is heilig en word deur die evangelie en die genade geregeer. Daarteenoor is die ryk van die wêreld sekulêr. Dit is die sfeer van die staat en word deur staatswette geregeer. Die heersende norm vir die ryk van die wêreld is geregtigheid.

Menseregte-aangeleenthede val binne die sfeer van die ryk van die wêreld (Du Toit, 1988:187). Die ryk van die wêreld word egter nog steeds deur God regeer. God se Wet het universele betekenis vir alle mense. Daarom gee sy Wet normatiewe beginsels vir sekulêre geregtigheidsbeginsels (Du Toit, 1988:37). Christene moet daarom 'n kritiese solidariteit toon met die handhawing van menseregte wêreldwyd, omdat die ryk van die wêreld ook die terrein is van God se voortdurende skepping (Vorster, 2002:187). 


\subsection{World Alliance of Reformed Churches}

Volgens die World Alliance of Reformed Churches (WARC) se Theological basis of human rights wat in 1976 verskyn het, het die mens nie inherent menseregte nie, maar dit is deur God aan hom gegee (WARC, 1976:51). Menseregte word in die skepping, verbond en koninkryk gefundeer. Moltmann (1977:130) vat die begronding van die WARC soos volg saam:

On the ground of the creation of man and woman in the image of God, on the ground of the incarnation of God for the reconciliation of the world, and on the ground of the coming of the kingdom of God as the consummation of history, the concern entrusted to Christian theology is one for the humanity of persons as well as for their ongoing rights and duties.

Die WARC erken eerste-, tweede- en derdegenerasieregte. Sosioekonomiese regte is net so belangrik soos politieke en burgerlike regte, en daarom moet alle menseregte beskerm en bevorder word (vgl. WARC, 1976:52; Moltmann, 1977:141, 142). Regte impliseer egter ook pligte. Die mens het pligte teenoor ander, omdat hy God se rentmeester oor die skepping is (WARC, 1976:52).

Die sonde het egter die mens as beeld van God korrup gemaak. Maar God se genade oorkom alle menslike tekortkomings en bring herstel in die handhawing van menseregte. Die kerk het daarom die taak om God se bevrydende genade aan die wêreld te verkondig (WARC, 1976:53). Omdat God die mens deur Jesus Christus van die sonde bevry het, moet die mens ook op politieke, sosiale en ekonomiese gebied bevry word van onderdrukking deur die erkenning van menseregte. Die bevryding van onderdrukking kan selfs revolusionêr wees (WARC, 1976:54-57). Hieruit is dit duidelik dat die WARC, soos die Politieke Teologie, klem lê op die konsep van bevryding. Jürgen Moltmann (1977:131) skryf byvoorbeeld vir die WARC:

According to the New Testament, Christian theology reflects the liberation of human beings from sin, law, and death through the coming, the sacrifice, and resurrection of Jesus Christ. In the lordship of the crucified Son of Man, the vicious circle of evil, which must bear even greater evil, is broken through, and the freedom of the children of God begins to appear. Liberation through the vicarious death of Christ, the new covenant in his blood, and the new rights and duties of the fellowship which is composed of slaves and freemen, Jews and gentiles, men and women (Gal. 3:28) are the basic content of the Biblical witness of the New Testament. 


\subsection{Die Gereformeerde Ekumeniese Raad}

Die Gereformeerde Ekumeniese Raad (GER) se Testimony on human rights wat in 1983 verskyn het, is die mees omvattende dokument oor menseregte binne die gereformeerde tradisie. In 1984 is hierdie dokument deur die sinode van Chicago aan ledekerke versprei, en sedertdien word hierdie dokument as 'n standardweergawe van die gereformeerde tradisie se siening van menseregte beskou.

In die prinsipiële fundering van menseregte hanteer die Testimony on human rights die Skrif as 'n geheel. Die openbaringshistoriese gang van die Skrif word as vertrekpunt gebruik met die skepping, sondeval en verlossing as die belangrikste draaipunte in die openbaringsgeskiedenis (RES, 1983:95).

Die prinsipiële fundering van menseregte begin by die skepping.

All creation, including all its creatures, especially human creatures as imagers of God, therefore find their right-of-existence and reason-of-existence in the service they owe their Maker. This divine claim, which rests fully, jointly, and equally upon us all, is the firm foundation upon which all human rights rests, prior to all else. (RES, 1983:96.)

Die mens wat na die beeld van God geskep is, se verhouding met die skepping en ander mense word deur sy verhouding tot God bepaal (RES, 1983:96, 97). Die mens se vertikale verantwoordelikheid teenoor God definieer sy horisontale verantwoordelikheid teenoor sy naaste (RES, 1983:96). Die plek van regte in menslike verhoudings word deur 'n driedimensionele perspektief bepaal, naamlik die individu se verantwoordelikheid teenoor ander, ander se verantwoordelikheid teenoor die individu, en die mense se gesamentlike verantwoordelikheid teenoor God. Deurdat die mens na die beeld van God geskep is, het hy menseregte van God ontvang en het hy die verantwoordelikheid gekry om ander se menseregte te respekteer en te bevorder (RES, 1983:100).

Deur Adam het alle mense gesondig en is die mens se beeldskap van God radikaal aangetas. Deur die sondeval het die skending van menseregte begin en word die lewe van die mens gekenmerk deur konflik (RES, 1983:103).

Direk na die sondeval begin God verlossing vir die mens bewerk. Deur Abraham kies Hy vir Hom 'n volk uit en begin om sy beeld in die mens te herstel (RES, 1983:105). Hy gee aan sy volk die Wet waardeur menseregte beskerm en gerespekteer moet word (RES, 
1983:105-107). In die Pentateug gee God verskeie wette vir die beskerming van menseregte. Ook die sosio-ekonomiese regte van armes, weduwees, weeskinders en vreemdelinge word op 'n besondere manier beskerm (RES, 1983:106-110).

Dit is veral die profete wat Israel se skending van sosio-ekonomiese regte kritiseer (RES, 1983:110-112). Die volk het egter die profete se boodskap verwerp en daarom het God hulle in ballingskap laat gaan. God skep egter die moontlikheid van verlossing, deur 'n oorblyfsel van Israel te laat terugkeer na hulle land. Hierdeur skep God weer 'n nuwe moontlikheid vir sy volk om sy beeldskap te vertoon, om in verantwoordelikheid voor sy aangesig te leef, en 'n nuwe verantwoordelikheid om menseregte te eerbiedig (RES, 1983:113).

Nie net die profete nie, maar ook die geskrifte sny die skending van sosio-ekonomiese regte aan. Die geskrifte roep Israel op tot die herstel van God se geregtigheid (RES, 1983:114-117).

Die beloftes van die Ou Testament vind hulle vervulling in die Nuwe Testament. Christus is die vervulling van die Wet, die profete en die geskrifte. Christus is die volmaakte beeld van God. Deur sy lewe, dood en opstanding het Hy die beeld van God in die gelowiges herstel (RES, 1983:117). Dit is die finale grondslag van alle menseregte. Want "almal wat Hom aangeneem het, dié wat in Hom glo, het Hy die reg gegee om kinders van God te word" (Joh. 1:12). Christus gee aan sy kerk die sendingopdrag as die "supreme declaration of human rights" (RES, 1983:117). Dit is die reg en verantwoordelikheid van alle mense om die evangelie te hoor en daarin te glo, maar dit is ook die reg en verantwoordelikheid van sy dissipels om dit te verkondig (RES. 1983:117).

Die Evangelies getuig daarvan hoe Jesus menseregte, en veral ook sosio-ekonomiese regte, beskerm. Christus reik uit na diegene wat in die oë van die Jode uitgeworpenes was, naamlik armes, herders, sondaars, vroue, Samaritane en heidene. Dit is veral Lukas wat fokus op die "poor and needy" (RES, 1983:118-121). Tydens sy hele lewe het Christus self die skending van sy menseregte ervaar, en veral ook tydens sy onregverdige verhoor deur Herodes en Pilatus, waarna dit 'n hoogtepunt bereik met sy versoenende dood aan die kruis. Deur sy opstanding herstel Christus alle regte, en deur sy hemelvaart en regering gaan Hy voort om alle regte te onderhou en te waarborg (RES. 1983:121).

$\mathrm{Na}$ sy hemelvaart het Christus nie die gelowiges alleen agtergelaat nie. Hy gee aan hulle sy Heilige Gees om sy verlossende werk in 
hulle lewe te aktualiseer. Pinkster is die begin van 'n diepe begeerte na geregtigheid. Dit het tot gevolg dat gelowiges versoening soek in menslike verhoudings, en dat die lewens van mense beskerm en bevorder word (RES, 1983:122). In die briewe van die Nuwe Testament, en veral in Romeine, word menseregte in die skepping en die versoenende werk van Jesus Christus gefundeer. Gelowiges word opgeroep om volgens die vervulde Wet van Christus te leef, naamlik in liefde en geregtigheid (RES, 1983:122, 123).

Terwyl gelowiges nog hier op aarde is, ervaar hulle die spanning van die koninkryk van God wat reeds gekom het, maar nog nie ten volle gekom het nie. Die skending van menseregte herinner daaraan dat God se verlossende plan nog in volheid moet kom. Die hele skepping is op pad na 'n nuwe hemel en aarde waar die skepping na sy oorspronklike bedoeling herskep gaan word, en waar menseregte eerbiedig gaan word (RES, 1983:124).

Die GER se Testimony on human rights eindig met 'n verklaring waarin die volgende menseregte erken word: die reg op lewe, die reg op basiese lewensbehoeftes, die reg op 'n huweliks- en familielewe, die reg op vryheid van aanbidding, die reg op godsdiensvryheid, die reg op werk, die reg op vryheid van assosiasie, die reg op politieke deelname, die reg op 'n vrye keuse van onderwys, die reg op vryheid van diskriminasie, die reg op gelyke toegang tot publieke administrasie en die reg op die gebruik van natuurlike hulpbronne. Die Gereformeerde Kerke in Suid-Afrika het sy hoë waardering vir die rapport uitgespreek (GKSA, 1985:651).

\section{Beoordeling van die vernaamste kerklike en teologiese tradisies se bydrae tot die etiek van sosio- ekonomiese regte}

- Die Rooms-Katolieke Kerk het 'n waardevolle bydrae tot sosioekonomiese regte gelewer deur die belangrikheid van hierdie regte te beklemtoon. Pous Leo XIII, wat die ekonomiese regte van die individu teenoor die sosialisme beklemtoon het, moet waardeer word. Die Rooms-Katolieke Kerk pleit vir die waardige behandeling van alle mense, ook op sosio-ekonomiese gebied. Die individu se verantwoordelikheid teenoor sy eie sosio-ekonomiese regte en dié van ander word ook positief beklemtoon.

Die Rooms-Katolieke Kerk se fundering van menseregte is egter problematies. Net soos by die humanisme, word menseregte in die natuurreg gefundeer. Menseregte word gefundeer in eienskappe wat die mens van nature sou besit, waarvan redelikheid 
en vryheid die vernaamste is. So 'n natuurregtelike fundering van menseregte kan nie prinsipieel aanvaar word nie. Dit is nie Skriftuurlik nie en dit hou nie rekening met die gevolge van die sondeval vir menseregte nie. Verder moet onthou word dat die mens nie van nature menseregte het nie, maar dat dit Godgegewe gawes aan die mens is. Volgens die Bybel besit die mens geen natuurlike regte los van God en sy medemens nie. Naas baie voorregte (in sy verhouding tot God), besit hy geskonke regte (in sy verhouding tot sy naaste) wat hy in vryheid en verantwoordelikheid moet uitleef (Van Wyk, 1991:254).

- Die WRK het daartoe bygedra dat sosio-ekonomiese regte onder die aandag van Westerse lande gebring is. Die WRK het die belangrikheid vir die beskerming van sosio-ekonomiese regte baie sterk beklemtoon. Prinsipieel kan die volgende kritiek egter teen die WRK gegee word:

- Die persepsie word geskep dat die WRK nie altyd as 'n kerklike liggaam funksioneer nie. Die rede hiervoor is dat die vergaderings van dié organisasie nie altyd volgens prinsipiële beginsels ingerig word nie, maar deur pragmatiese en politieke oorwegings. Hierdie feit, saam met die feit dat die WRK tussen 1966 en 1975 revolusionêre geweld goedgepraat het, skep die indruk dat die WRK die gevaar loop om as 'n politieke organisasie te funksioneer.

- Die WRK moet daarteen waak om sekulêre menseregteteorieë onkrities oor te neem. Sosio-ekonomiese regte moet prinsipieel uit die Skrif gefundeer word en op 'n verantwoordelike wyse bevorder en beskerm word. Kerklike liggame moet daarteen waak om sosio-ekonomiese regte te verpolitiseer.

- Enige kerklike organisasie moet onthou dat verkeerde ekonomiese en sosiale strukture by die mens se sondige aard begin. Daarom moet die kerk God se boodskap van verlossing van sonde duidelik bly verkondig. Wanneer die Heilige Gees deur God se Woord mense se harte verander, verander die sondige strukture ook. Natuurlik moet sondige strukture ook gekritiseer en verander word, maar 'n boodskap wat net gaan oor die bevryding van ekonomiese en sosiale strukture, is 'n verskraling van die Bybelse verlossingsboodskap. Die WRK skep die persepsie dat die bevryding van ekonomiese en sosiale nood al is waaroor verlossing gaan. 
- Net soos by die WRK, slaag die Lutherse tradisie nie daarin om 'n goeie Skriftuurlike fundering vir menseregte te gee nie. Die groot rede hiervoor is die Lutherse Kerk se tweeterreineleer. Sekulêre begrondings van menseregte word te maklik aanvaar, omdat dit gesien word as deel van die domein van die wêreld. Volgens die Lutherse Kerk word die domein van die wêreld nie deur die evangelie regeer nie, maar deur menslike wette. Prinsipieel staan die staat (en alle ander lewensverbande) onder die heerskappy van Christus. Die Christelike etiek het daarom 'n belangrike roeping in elke lewensverband.

- Die WARC gee in The theological basis of human rights 'n goeie fundering aan menseregte deur gebruik te maak van skepping, verbond en koninkryk as Skriftuurlike beginsels. Eerste-, tweedeen derdegenerasieregte word erken, asook die mens se pligte teenoor die ander omdat hy God se rentmeester oor die skepping is. Die WARC se dokument oor menseregte is ongelukkig deur die politieke teologie beïnvloed. Dit wil amper voorkom asof die bevryding van die mens van onderdrukkende ekonomiese en sosiale strukture as die hoogste doel gestel word.

- Die GER se Testimony on human rights is 'n deeglike studie oor die fundering van menseregte, en daarmee ook sosio-ekonomiese regte. Deur die openbaringshistoriese gang van die Skrif as vertrekpunt te gebruik, met die skepping, sondeval en verlossing as die belangrikste draaipunte in die openbaringsgeskiedenis, kom die hele Skrif tot sy reg in die fundering van menseregte. Hierdie studie sou egter meer volledig gewees het indien Bybelse temas ook gebruik is om menseregte te fundeer - temas soos geregtigheid, liefde, barmhartigheid, waarheid en vryheid.

\section{Samevatting en gevolgtrekking}

Die konsep van menseregte, soos ons dit vandag ken, is 'n relatief nuwe konsep. Tog is menseregte in 'n Bybelse sin nie iets nuuts nie. Menseregte in 'n Bybelse sin gaan terug tot by die skepping van die wêreld toe God die mens na sy beeld geskep het (Van Wyk, 1993:18). Die mens het bloot die afgelope paar eeue begin om die leerstuk van menseregte te formuleer en as fundamentele regte in grondwette te erken. Kerke moet dus deelneem aan die menseregtediskoers en profetiese getuienis gee oor Bybelse menseregte, wat sosio-ekonomiese regte insluit. 


\section{Geraadpleegde bronne}

BROECKX, K.E. 1946. Rerum novarum en quadragesimo anno. 6e uitg. Antwerpen: De Vlijt.

CALVYN, J. 1984. Commentaries on the epistle of Paul the apostle to the Romans. Translated from the original Latin by John Owen. Grand Rapids: Baker.

DE VILLIERS, D.E. 1984. Die geskiedenis van menseregte. (In Du Toit, D.A., red. Menseregte. Kaapstad: Tafelberg. p. 9-39.)

DU TOIT, D.A. 1988. Die mens en sy regte: geloof en praktyk in Suid-Afrika. Kaapstad: Zebra.

GEREFORMEERDE KERKE IN SUID-AFRIKA. 1985. Handelinge van die tweeGKSA en-veertigste nasionale sinode. Potchefstroom: Potch Herald.

$k y k$ GEREFORMEERDE KERKE IN SUID-AFRIKA

JOHN XXIII. 1963. Pacem in terris. (In Fremantle, A., ed. The papal encyclicals in their historical context: the teaching of the popes from Peter to John XXIII. New York: New American Library. p. 180-424.)

LEO XIII. 1946. Rerum novarum. (In BroeckX, K.E. Rerum novarum en quadragesimo anno. 6e uitg. Vertaal uit de Latijn door K.E. Broeckx. Antwerpen: De Vlijt. p. 206-344.)

LUTHERAN WORLD FEDERATION. 1978. Theological perspectives on human rights. Church and society, 69(2):45-46.

LWF

see LUTHERAN WORLD FEDERATION

MOLTMANN, J. 1977. A definitive study paper: a Christian declaration on human rights. (In Miller, A.O. A Christian declaration on human rights: theological studies of the World Alliance of Reformed Churches. Grand Rapids: Eerdmans. p. 129-143.)

PIUS XI, 1946. Quadragesimo anno. (In Broeckx, K.E. Rerum novarum en quadragesimo anno. 6e uitg. Vertaal uit de Latijn door K.E. Broeckx. Antwerpen: De Vlijt. p. 297-344.)

REFORMED ECUMENICAL SYNOD. 1983. Testimony on human rights. Grand Rapids: RES.

RES

see REFORMED ECUMENICAL SYNOD

VAN DER VYVER, J.D. 1975. Die beskerming van menseregte in Suid-Afrika. Kaapstad: Juta.

VAN WYK, J.H. 1991. Moraliteit en verantwoordelikheid: opstelle oor politieke etiek. Potchefstroom: $\mathrm{PU}$ vir $\mathrm{CHO}$.

VAN WYK, J.H. 1993. Homo Dei: 'n prinsipiële besinning oor enkele mensbeskouings, waaronder dié van Calvyn. In die Skriflig, 26(4):551-562.

VORSTER, N. 2002. Kerk en menseregte binne 'n regstaat: die profetiese roeping van die kerk ten opsigte van die vestiging van 'n etos van WARC menseregte in Suid-Afrika. Potchefstroom: PU vir CHO. (Th.D.- proefskrif.) WCC

$k y k$ WORLD ALLIANCE OF REFORMED CHURCHES

kyk WORLD COUNCIL OF CHURCHES

WORLD ALLIANCE OF REFORMED CHURCHES. 1976. Theological basis of human rights. Geneva. 
WORLD COUNCIL OF CHURCHES. 1968. Uppsala 1968 speaks: section reports of the fourth assembly of the World Council of Churches. New York.

WORLD COUNCIL OF CHURCHES. 1974. Report on working group A: the right to life and work: the basic social, economic and cultural rights. (In World Council of Churches. Human rights and Christian responsibility: report of the consultation St. Pölten, Austria. Geneva. p. 35-38.)

WORLD COUNCIL OF CHURCHES. 1975a. Breaking barriers Nairobi 1975: the official report of the fifth assembly of the World Council of Churches, Nairobi, 23 November-10 December. London: SPCK.

WORLD COUNCIL OF CHURCHES. 1975b. Uppsala to Nairobi. London: SPCK.

WORLD COUNCIL OF CHURCHES. 1987. Diakonia 2000: called to be neigbours. Official report World Council of Churches world consulation, inter-church aid, refugee and world service, Larnaca 1986. Geneva.

WORLD COUNCIL OF CHURCHES. 1991. Signs of the Spirit: official report of the Seventh Assembly. Grand Rapids: Eerdmans.

WORLD COUNCIL OF CHURCHES. 1999. Together on the way. Official report of the eighth assembly of the World Council of Churches: the new challenges. Geneva.

\section{Kernbegrippe:}

kerk

menseregte

sosio-ekonomiese regte

teologies-eties

\section{Key concepts:}

church

human rights

socio-economic rights

theological-ethical 